\title{
Seasonal changes of benthic and epiphytic dinoflagellates in the Veracruz reef zone, Gulf of Mexico
}

\author{
Yuri B. Okolodkov ${ }^{1, *}$, Guadalupe Campos-Bautista ${ }^{2}$, Ismael Gárate-Lizárraga ${ }^{3}$, \\ José Antonio Guillermo González-González ${ }^{4}$, Mona Hoppenrath ${ }^{5}$, Virgilio Arenas ${ }^{1}$ \\ ${ }^{1}$ Centro de Ecología y Pesquerías, Universidad Veracruzana, Calle Hidalgo No. 617, Col. \\ Río Jamapa, Boca del Río, CP 94290, Veracruz, Mexico \\ ${ }^{2}$ Acuario de Veracruz, Blvd. Manuel Ávila Camacho s/n, Playón de Hornos, CP 91700, Veracruz, Mexico \\ ${ }^{3}$ Centro Interdisciplinario de Ciencias Marinas, CICIMAR-IPN, Departamento de Plancton y Ecología Marina, \\ AP 592 La Paz, 23000 Baja California Sur, Mexico \\ ${ }^{4}$ Instituto Oceanográfico del Golfo y Mar Caribe, Secretaría de Marina, Playa del Este s/n, El Salado, \\ Antón Lizardo, CP 95263, Veracruz, Mexico \\ ${ }^{5}$ University of British Columbia, Department of Botany, 6270 University Blvd., Vancouver, British Columbia V6T 1Z4, Canada
}

\begin{abstract}
Benthic/epiphytic dinoflagellates were monitored every 2 wk from May to December 2005 in the Veracruz reef zone, Gulf of Mexico. This assemblage was characterized by low species diversity (at least 17 species from 11 genera) and high abundance: Amphidinium cf. carterae (41172 cells $\mathrm{g}^{-1}$ substrate wet weight), Prorocentrum lima (29756 cells $\mathrm{g}^{-1}$ ), Coolia monotis

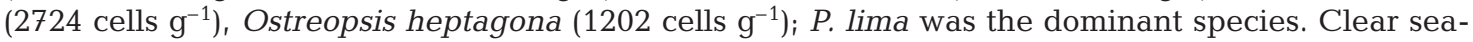
sonal population dynamics occurred, with the highest abundance in May-June, and the dynamics differed at 2 neighbouring sampling sites. In August to December dinoflagellate abundance decreased considerably. Most of the epiphytic dinoflagellates did not show any significant preference for a macrophyte substrate (23 macroalgal and 2 seagrass species) or for any species or major algal group, although the seagrass Thalassia testudinum appeared to be the most abundant and permanent host species. The highest abundance of $P$. lima occurred on the chlorophyte Ulva fasciata (30 879 cells g ${ }^{-1}$ ) and $T$. testudinum (31467). Dinoflagellates were usually scarce on dead coral (Acro-

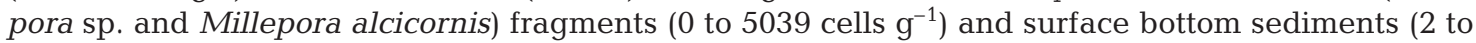
84), and were slightly more abundant on living Diploria strigosa (329 to 1830) and more numerous in a fringing reef zone compared to a reef lagoon near an offshore island. Dinoflagellate abundance was not correlated with any measured physical or chemical parameter (temperature, salinity, pH, dissolved oxygen, nitrates, nitrites, ammonium, phosphates, precipitation or wind speed and direction). There is a high potential for outbreaks of ciguatera in the studied area.
\end{abstract}

KEY WORDS: Dinophyceae · Benthic · Epiphytic · Seasonal changes · Coral reefs · Ciguatera · Gulf of Mexico · Mexico

\section{INTRODUCTION}

Benthic and epiphytic dinoflagellates (Dinophyceae) in the southern Gulf of Mexico have been outside the scope of studies or monitoring programs. Two reports are known from the Mexican Caribbean (Almazán-
Becerril 2000, Hernández-Becerril \& Almazán-Becerril 2004). Ciguatera fish poisoning in the coastal waters of the state of Baja California Sur in the NW Mexican Pacific and the states of Quintana Roo (Mexican Caribbean) and Yucatan (southeastern Gulf of Mexico) was reported 291 times over 16 yr (Parrilla-Cerrillo et 
al. 1993, Núñez-Vázquez et al. 2000). Some benthic species such as Coolia monotis, Gambierdiscus toxicus, Prorocentrum lima, P. belizeaum M. A. Faust, Sinophysis canaliculata and Ostreopsis spp. are known from the Mexican Pacific (for detailed information, see Okolodkov \& Gárate-Lizárraga 2006). In Cuban waters, an extensive multi-year epidemiological study of ciguatera was performed in Ciego de Ávila province (Suárez-Hernández et al. 2001). In the Caribbean basin in general, sampling has been mainly in the eastern part of the region (Besada et al. 1982, Carlson \& Tindall 1985, Ballantine et al. 1988, Lobel et al. 1988, Tindall et al. 1990, Heil et al. 1993, Bourdeaux et al. 1995, Tosteson et al. 1998).

In the tropical zone, especially in coral reef environments, benthic and epiphytic dinoflagellates have been found to be associated with seagrasses, brown and red algae, dead corals and sediments (Taylor 1979, Fukuyo 1981, Carlson \& Tindall 1985, Ballantine et al. 1988, Bagnis et al. 1990, Faust 1990, 1995a,b, Tindall et al. 1990, Heil et al. 1993, 1998, Bourdeaux et al. 1995, Morton \& Faust 1997, Tosteson et al. 1998, Turquet et al. 1998, Pearce et al. 2001, Delgado et al. 2002, 2005). Sand-dwelling dinoflagellates are known from tropical and subtropical areas (e.g. Horiguchi \& Chihara 1987, Faust 1990, Faust \& Balech 1993, Horiguchi et al. 2000, Ten-Hage et al. 2001, Horiguchi \& Sukigara 2005, Tamura et al. 2005, Murray et al. 2006a,b) but are better known from temperate regions (e.g. Herdman 1921, Balech 1956, Baillie 1971, Larsen 1985, Dodge \& Lewis 1986, Faust 1995b, Horiguchi 1995, Hoppenrath 2000a,b,c,d, Hoppenrath et al. 2003, 2004).

Seasonal/annual and interannual dynamics of benthic and epiphytic dinoflagellate assemblages in a reef zone have been studied in the Virgin Islands (Carlson \& Tindall 1985), in French Polynesia (Bagnis et al. 1985), Puerto Rico (Ballantine et al. 1988), on Singapore reefs (Holmes et al. 1998), on Réunion Island (Turquet et al. 1998), and in the NW Mediterranean (Vila et al. 2001).

Species richness in benthic and epiphytic dinoflagellate assemblages is usually lower than that in planktonic ones. In the most comprehensive taxonomicecological study to date, 39 species from 12 genera, including unidentified taxa, were found (Turquet et al. 1998). Epiphytic dinoflagellates may show distinct substrate preferences (Shimizu et al. 1982, Carlson \& Tindall 1985, Lobel et al. 1988, Heil et al. 1998).

In the present study, our objectives were: (1) to determine the species composition of benthic and epiphytic dinoflagellates, with an emphasis on numerically dominant species, inhabiting the port of Veracruz area, Mexico; (2) to determine the range of habitats for benthic and epiphytic dinoflagellates; (3) to relate the presence and abundance of dinoflagellates with various macrophyte substrates; (4) to evaluate seasonal changes of benthic and epiphytic dinoflagellates; (5) to determine the physical-chemical variables and their relation to the abundance of dinoflagellates; and (6) to evaluate the risk of benthic and epiphytic dinoflagellates to the ecosystem and the human community.

\section{MATERIALS AND METHODS}

Sampling of benthic and epiphytic dinoflagellates was a part of a monitoring program of harmful algal blooms launched on 10 May 2005 by the Aquarium of Veracruz and the Center of Ecology and Fisheries of the University of Veracruz (CEF-UV). Dinoflagellates were taken every 2 wk from 10 May through 13 December 2005, between 11:30 and 14:00 h, at 2 permanent stations (16 surveys in total) in the National Park Sistema Arrecifal Veracruzano (NPSAV), state of Veracruz, Mexico, located in the coastal zone of the southern Gulf of Mexico: Stn 3, a reef lagoon always open to the sea, ca. 150 to $200 \mathrm{~m}$ from Isla de Sacrificios (also classified as shallow, slightly subtidal, permanently submerged reef flats extending into a lagoon, thus belonging to the type II system according to Tindall \& Morton 1998) was at $19^{\circ} 10^{\prime} 32.7^{\prime \prime} \mathrm{N}$, $96^{\circ} 05^{\prime} 40.9^{\prime \prime} \mathrm{W}$; and $\mathrm{Stn} 5$, a semi-protected shallow area with a sandy bottom covered with coral rubble, the remnants of a fringing reef without live corals, ca. $50 \mathrm{~m}$ from the coastline, was at $19^{\circ} 10^{\prime} 37.4^{\prime \prime} \mathrm{N}$, $96^{\circ} 07^{\prime} 10.9^{\prime \prime} \mathrm{W}$ (Fig. 1). It is difficult to ascribe our sampling sites to a particular type of system due to the lack of geomorphological studies. However, both sites clearly belong to the type I or II system because of their nearly constant, moderate to strong water flow, depth range (usually more than $0.5 \mathrm{~m}$, sometimes down to $0.3 \mathrm{~m}$ at low tide), and oligotrophic conditions (Tindall \& Morton 1998). In accordance with Schuhmacher's (1978) classification of principal reef zones, we consider our sampling sites as reef moats. Samples were collected by snorkeling. At permanent stations the depth was 0.5 to $1.2 \mathrm{~m}$. Seagrass (50 to $170 \mathrm{~g}$ ) was sampled manually from an area of less than $10 \mathrm{~m}^{2}$ (usually from $<1 \mathrm{~m}^{2}$ ); only blades were taken and were placed immediately into $500 \mathrm{ml}$ plastic bottles. The seasonally dominant species of macroalgae (20 to $100 \mathrm{~g}$, depending on their availability) were detached gently from the substrate manually or with a knife and sorted according to species; these were placed into plastic bottles underwater. Dead coral fragments (predominantly those of Millepora alcicornis L. and Acropora sp.; 300 to $1000 \mathrm{~g}$ ) covering the sea bottom were collected manually and placed into plastic bottles of 500 to $1500 \mathrm{ml}$ capacity. Sediments (200 to $700 \mathrm{~g}$ ) were col- 


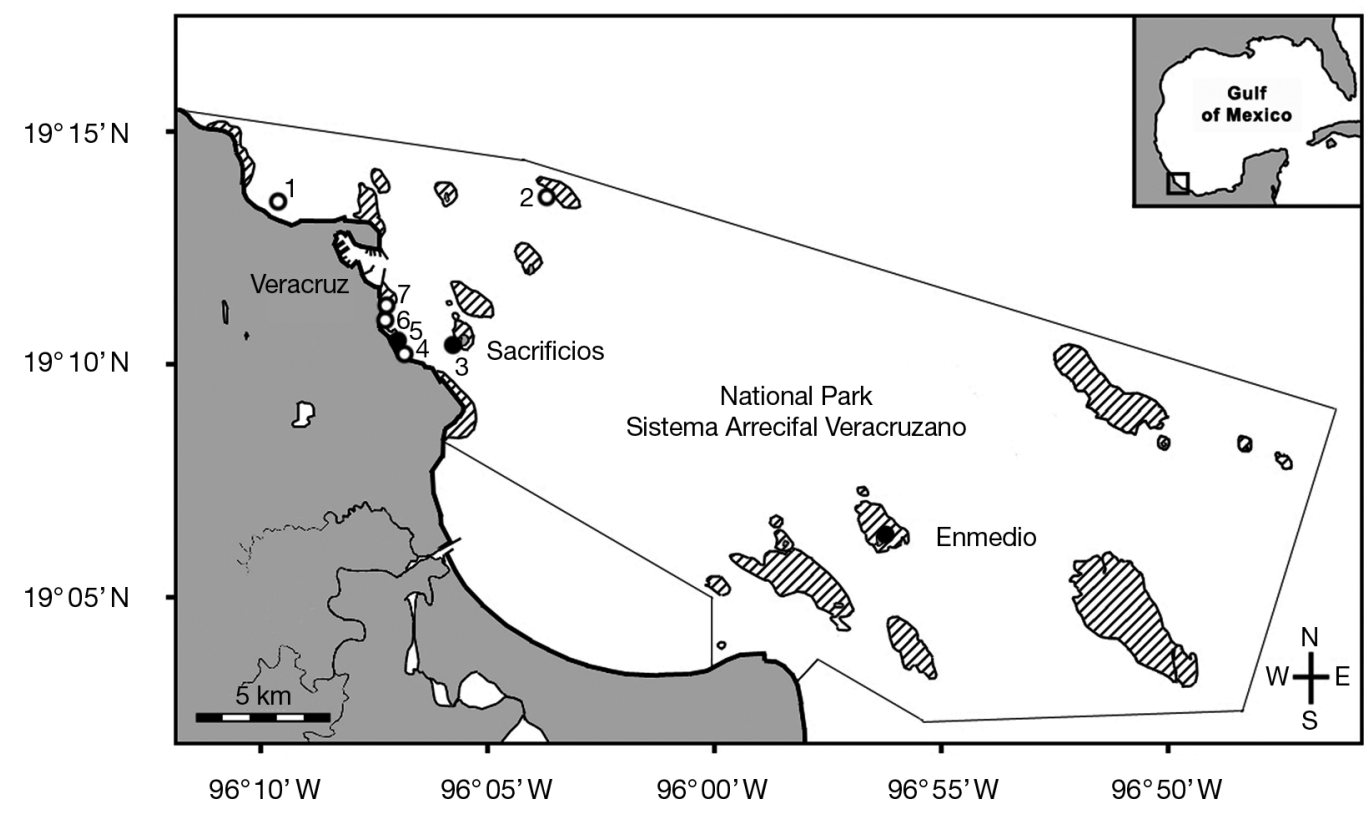

Fig. 1. Sampling sites in the National Park Sistema Arrecifal Veracruzano. @: locations where planktonic, benthic and epiphytic dinoflagellates were sampled. O:phytoplankton sampling sites. Hatched areas are coral reefs; the line indicates the park boundary

lected using a plastic bottle directly from the sea bottom. In 2 cases, sediments associated with turf macroalgae growing on top of large colonies of Diploria strigosa (Dana) were collected with a knife and carefully placed into a plastic bottle. All the samples were taken together with the surrounding seawater and transported to the boat, where $37 \%$ formalin was added to the bottles to a final concentration of $5 \%$. On some occasions, the macroalgae attached to buoys and drifting Sargassum spp. were sampled and treated similarly. The buoys were taken from the water into the boat, and the macroalgae attached to the plastic globe and the rope (down to about $5 \mathrm{~m}$ below the globe) were separated with a knife and transferred to a plastic bottle. Two buoys were sampled on 10 January and 23 March 2006 at Stn 2 (15 samples in total). Drifting Sargassum spp. were taken on 13 December 2005, and 10 and 21 February 2006 en route between Stns 1 and 2. In total, 221 samples were analyzed quantitatively: 104 samples of macroalgae, 38 of seagrasses, 36 of surface sediments, 23 of dead corals, 2 of sediment from live corals, 11 from buoys, and 7 of drifting macroalgae.

In the laboratory, each sample was thoroughly mixed to remove epiphytes. Each sample was placed into a 11 beaker, and macrophytes were washed manually to better separate dinoflagellate cells. Macrophytes were squeezed by hand to avoid excessive liquid. When Thalassia testudinum blades contained macroalgal epiphytes, they were scrubbed with a plastic or steel knife and mixed. Macrophytes were then weighed with an Ohaus ES6R balance. The volume of liquid was measured in a glass or plastic graduated cylinder. The procedure for dead corals or sediments was simpler: they were separated from liquid and weighed, and the volume of liquid was measured. When a macrophyte sample contained sediment (e.g. Caulerpa spp.), it was considered a part of the substrate for dinoflagellates; the weight of sediment was added to that of the macrophyte, and the total wet weight was calculated.

A $1 \mathrm{ml}$ aliquot of the liquid containing benthic and epiphytic dinoflagellates was taken and transferred to a Sedgwick-Rafter counting chamber. For sediment samples, an aliquot was taken 30 to $40 \mathrm{~s}$ after shaking to allow heavy inorganic particles to settle. One or 2 drops of $0.2 \%$ Trypan Blue solution were added to the counting chamber to facilitate counting of thecate species (Lebour 1925, Taylor 1978). Depending on the quantity of the larger cells, the whole chamber or only a part of it was scanned, and the cells were identified and counted using a Nikon Eclipse TS100 inverted microscope equipped with phase contrast objectives $(10 \times / 1.25$ Ph1 ADL (Apodized Dark Low) WD 6.2 and LWD (Long Working Distance) $20 \times / 0.40$ Ph1 ADL WD 3.1). Smaller cells (e.g. those of Amphidinium cf. carterae) were counted in a bright field using a LWD $40 \times / 0.55 \mathrm{Ph} 1 \mathrm{ADL}$ WD 3.1 objective in 3 to 10 transversal bands depending on the number of cells found. The number of cells of different species was recalculated for the whole chamber and then per gram of host macrophyte, coral or sediment substrate wet weight (Bagnis et al. 1985, Bomber et al. 1985, 1988, 1989, Del- 
gado et al. 2005), taking into account the total volume of the liquid fraction in the sample (the volume of liquid corresponding to $1 \mathrm{~g}$ of the substrate's wet weight). Cells were measured using a $10 \times$ eyepiece containing a micrometer disc and a $40 \times$ objective. Photographs for further identification were taken using a Nikon Coolpix S4 digital camera adapted to the microscope.

Temperature, $\mathrm{pH}$ and dissolved oxygen (DO) of the surface layer of water were recorded on board using a multiparameter meter Multi 197i (WTW Measurement Systems). Salinity was measured with a refractometer (Aquatic Ecosystem). Samples of DO, dissolved inorganic nitrogen (DIN) and dissolved phosphate $\left(\mathrm{NO}_{3}-\mathrm{N}\right.$, $\mathrm{NO}_{2}-\mathrm{N}, \mathrm{NH}_{4}-\mathrm{N}$ and $\mathrm{PO}_{4}-\mathrm{P}$ ) were collected in $8 \mathrm{l}$ plastic tanks from the surface layer. Determinations of DO and nutrients were made in the laboratory using a portable data logging spectrophotometer Hach DR/ 2010. Precipitation, wind speed and direction graphs were averaged from the daily data obtained by the Meteorological Observatory of the National Commission of Water (Centro de Previsión del Golfo de México, Subgerencia Técnica, Gerencia Regional Golfo Centro, Comisión Nacional del Agua, Veracruz, México; $19^{\circ} 08^{\prime} 34.4^{\prime \prime} \mathrm{N}, 96^{\circ} 06^{\prime} 39.2^{\prime \prime} \mathrm{W}$ ).

Factor analysis was used to clarify relationships between the species composition of benthic/epiphytic dinoflagellates and physical-chemical characteristics. The abundance of each species and the values of different variables were incorporated into an agglomerative classification module. In the analysis, an $r$ and $q$ matrix was computed separately with the variables using a varimax rotation. Factor analysis was performed using STATISTICA software (Version 6, 1994 to 2001).

Although our studies of benthic and epiphytic dinoflagellates cover the period from May through December 2005, we present the annual dynamics of environmental conditions throughout the year from May 2005 through May 2006 for a better understanding of the seasonal changes of dinoflagellate taxocoenosis in relation to physical-chemical factors.

\section{RESULTS}

\section{Physical-chemical conditions}

Physical-chemical conditions differed slightly between the 2 main sampling sites. The $\mathrm{pH}$ of the surface layer of the water in May to July fluctuated a little more at Stn 5 than at Stn 3, while in September to October fluctuations were much more pronounced at Stn 3 (Fig. 2).

From May through October 2005, easterly and northerly winds predominated (Figs. 3 \& 4). Strictly northerly winds prevailed in October (for $17 \mathrm{~d}$ ). From November to December, northwesterly winds blew for $22 \mathrm{~d}$ (according to the average values shown in Fig. 3, southerly winds prevailed; however, it does not hold true in this case due to the inadequacy of applying mean values expressed on a $360^{\circ}$ scale). In March to May 2006, easterly and northeasterly winds took over. Average wind speed remained between 2.8 and $4.0 \mathrm{~m} \mathrm{~s}^{-1}$ throughout the year, and minimal monthly values varied between 1.0 and $2.5 \mathrm{~m} \mathrm{~s}^{-1}$ (Fig. 3). The maximal average monthly wind speed peaked in July and November 2005 (during the sampling period at Stns 3 and 5) and in January and February 2006, reaching 8.5, 10.7, 11.9 and $10.6 \mathrm{~m}$ $\mathrm{s}^{-1}$, respectively. The minimal average monthly wind speed values were recorded in August and December 2005.

The diurnal tidal range near Veracruz reaches 95 to $105 \mathrm{~cm}$ (calculated from González et al. 2006 [Oceanografía Física, CICESE], available at: http:// oceanografia.cicese.mx/predmar/). Temperature and salinity curves from both Stns 3 and 5 are similar (Fig. 5A,B), with mean maximum temperatures in June and October 2005 and a slightly decreased salinity in July $(<29)$. Average daily precipitation steadily increased from May and peaked in October, abruptly decreased in October to November (with the lowest daily precipitation of $277.3 \mathrm{~mm}$ in October 4), reached

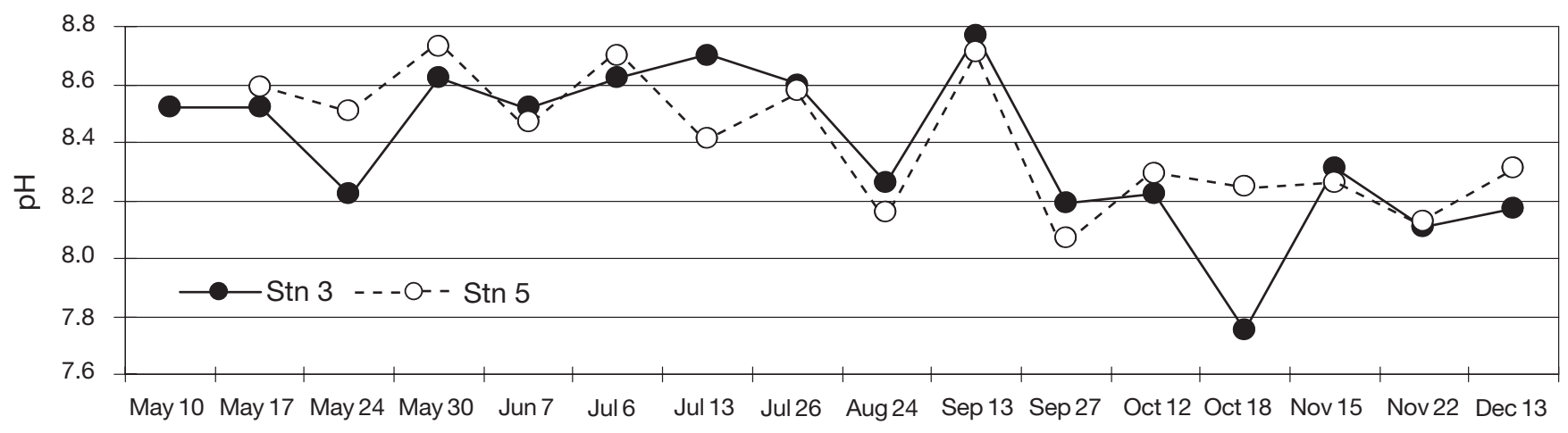

Fig. 2. Annual variability of pH in the water column at Stns 3 and 5 in 2005 in the National Park Sistema Arrecifal Veracruzano. See Fig. 1 for station locations 


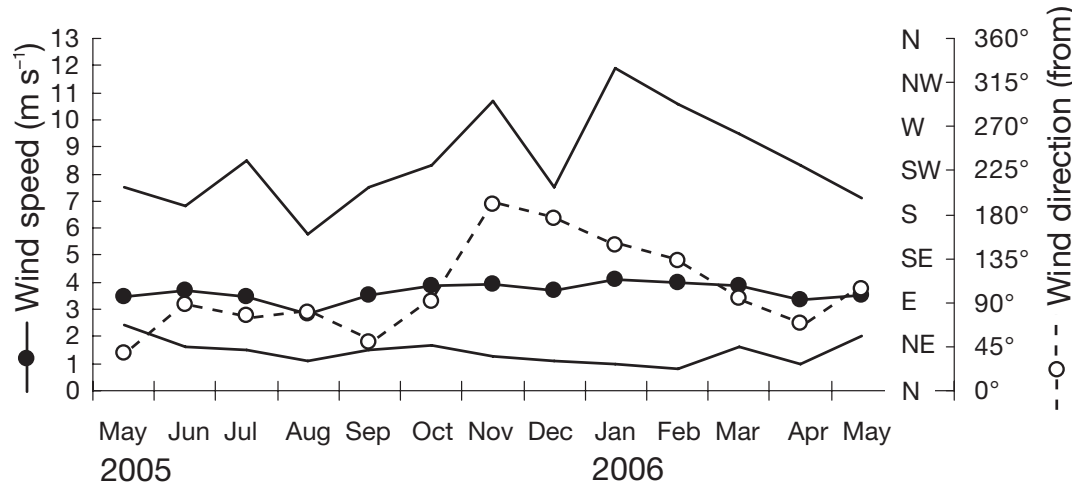

Fig. 3. Annual variability of average monthly wind speed and direction in the National Park Sistema Arrecifal Veracruzano. Solid lines (without symbols) indcate maximum and minimum wind speed

its minimal values in December 2005, and maintained very low levels until May 2006 (Fig. 5C,D). DO concentrations usually correspond with the percentage of oxygen saturation at both Stns 3 and 5 throughout the year except in October (Fig. 5E,F). DIN varied slightly throughout the year and peaked in October 2005 and February 2006, almost reaching $1.5 \mathrm{mg} \mathrm{l}^{-1}$ (Fig. 5G,H). $\mathrm{PO}_{4}$-P concentrations for the most part also varied slightly; however, a high peak of $2.2 \mathrm{mg} \mathrm{l}^{-1}$ was registered at Stn 3 in July 2005.

\section{Species composition of benthic/ epiphytic dinoflagellates and associated macrophytes}

The number of species of benthic and epiphytic dinoflagellates at Stns 3 and 5 was comparatively low; 17 species were identified to specific and generic level (Fig. 6, Table 1). Few cells of Gambierdiscus were found, and the identification of its 2 species remains preliminary. The identification of athecate dinoflagellate taxa is problematic when dealing with fixed cells. The cell shape can be changed, and the chloroplast morphology is difficult to determine. Therefore, and because a very similar species exists but has not been recorded for the area yet, we hesitate to assign the Amphidinium species unambiguously and have recorded it as $A$. cf. carterae. Twentythree macroalgal and 2 seagrass species were found associated with epiphytic dinoflagellates (Table 2). Some macroalgal species remain unidenti- fied. The seagrass Syringodium filiforme was found only near Isla de Enmedio on 9 April 2005 (1906' 10.7" N, $\left.95^{\circ} 56^{\prime} 18.7^{\prime \prime} \mathrm{W}\right)$ as a band located closer to the coastline (between 10 and $20 \mathrm{~m}$ from it) than the extensive zone of Thalassia testudinum.

\section{Abundance of benthic/epiphytic dinoflagellates}

A minimal range of abundance of benthic dinoflagellates occurred in sediments on dead corals and in bottom sediments, and maximal values of abundance occurred on Thalassia testudinum and Ulva fasciata (Table 1). Sediments on top of the live coral Diploria strigosa contained more dinoflagellate cells than sediments on dead corals spread over the bottom.

On comparing Stns 3 and 5, one can see that (1) cell abundances in bottom sediments are low and almost equal, (2) cell abundance on dead corals at Stn 3 is considerably higher than at Stn 5, (3) dinoflagellate cell abundance found with the macroalgal species Caulerpa sertularioides and C. cupressoides is higher at Stn 5, and (4) while Halimeda opuntia was typical of Stn 3, Acanthophora spicifera and Ulva fasciata were characteristic of Stn 5 (Table 1).
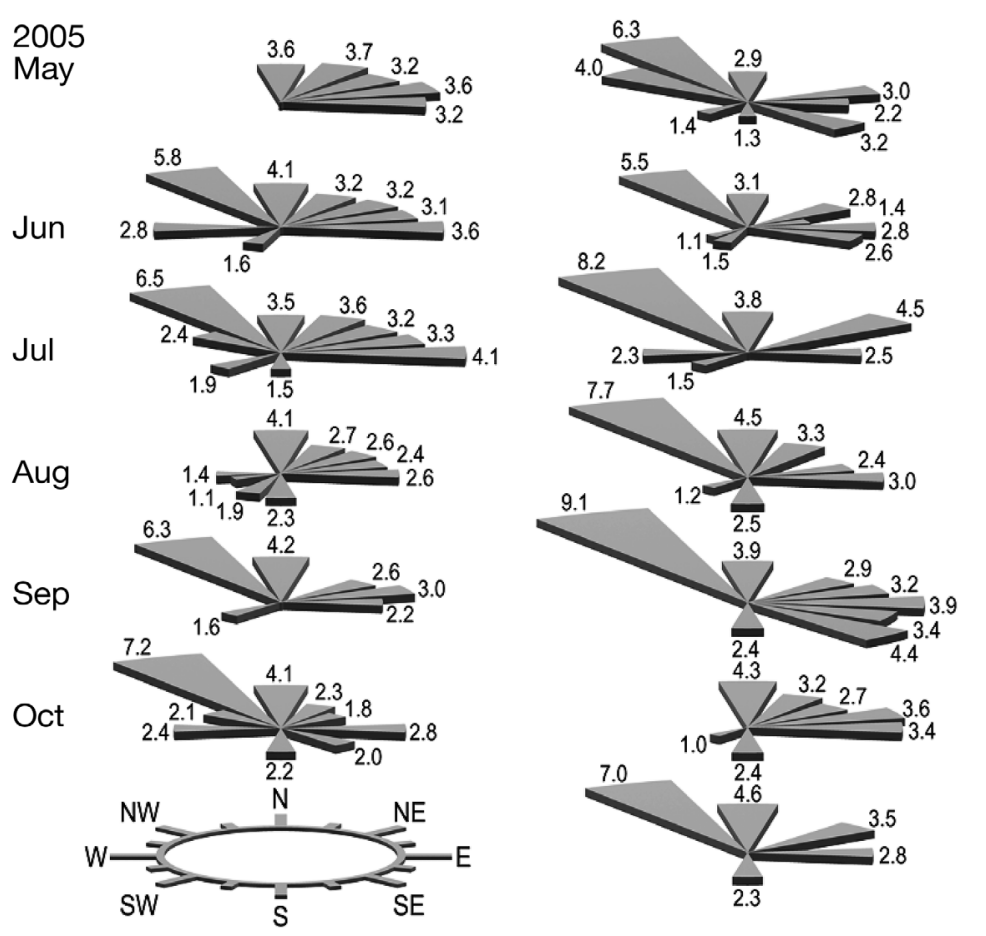

Nov

Dec

2006

Jan

Feb

Mar

Apr

May

Fig. 4. Monthly wind speed $\left(\mathrm{m} \mathrm{s}^{-1}\right)$ averaged according to direction in the National Park Sistema Arrecifal Veracruzano 

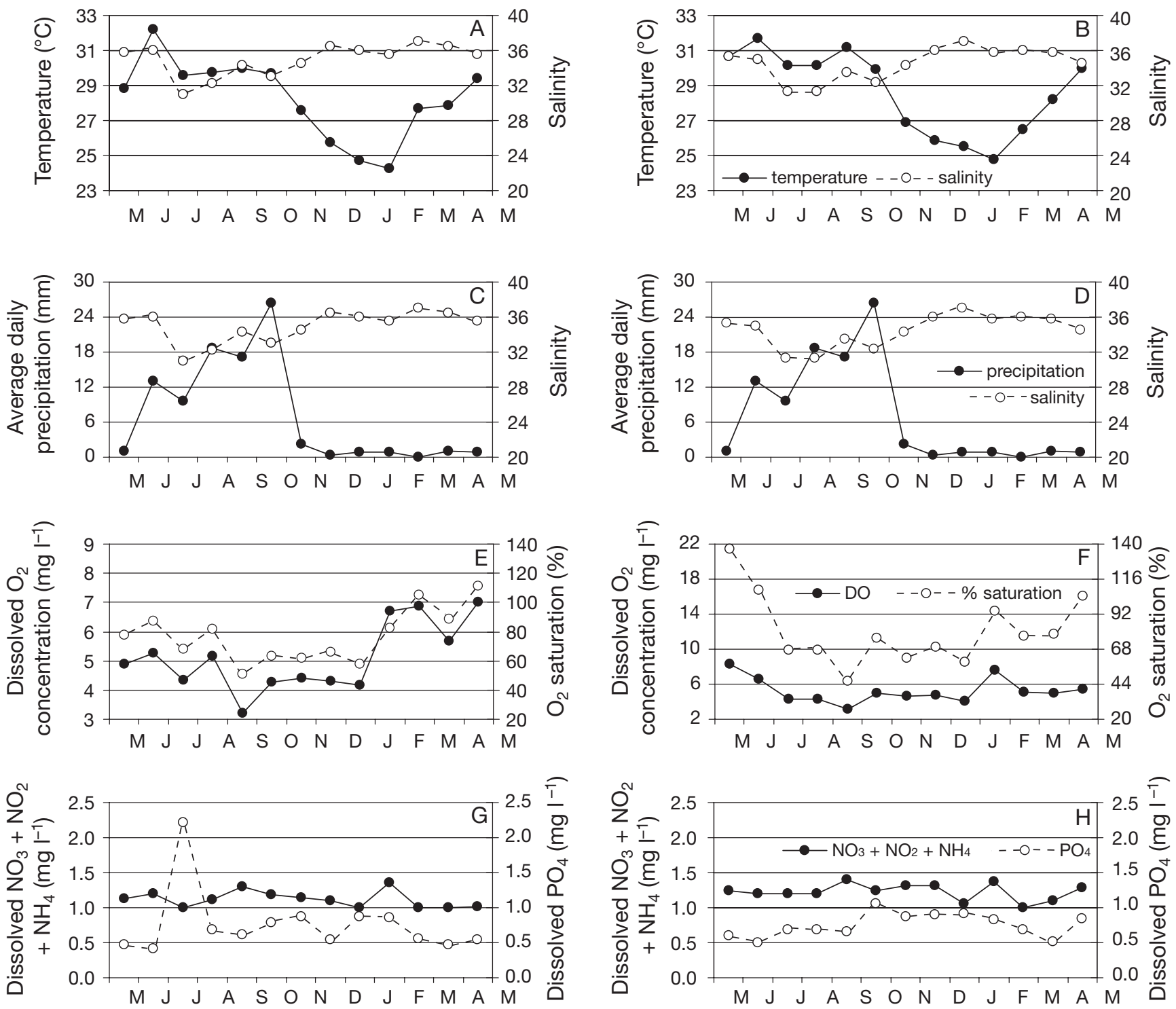

Fig. 5. Annual variability of some physical and chemical characteristics of the water column at (A,C,E,G) Stn 3 and (B,D,F,H) Stn 5 in the National Park Sistema Arrecifal Veracruzano. (A,B) Water temperature and salinity; $(C, D)$ precipitation and salinity; (E,F) dissolved oxygen (DO) concentration and percentage of oxygen saturation; $(\mathrm{G}, \mathrm{H})$ dissolved inorganic nitrogen $\left(\mathrm{NO}_{3}-\mathrm{N}+\right.$ $\left.\mathrm{NO}_{2}-\mathrm{N}+\mathrm{NH}_{4}-\mathrm{N}\right)$ and phosphate $\left(\mathrm{PO}_{4}-\mathrm{P}\right)$ concentrations. See Fig. 1 for station locations

Factor analysis results are not shown because no significant relationship between benthic/epiphytic dino-flagellates and the physical-chemical characteristics was observed.

\section{Seasonal changes of benthic/epiphytic dinoflagellates}

Macrophytobenthos, dead corals and sediments were collected every $2 \mathrm{wk}_{\text {; }}$ however, a continuous record was obtained only for the Thalassia testudinum association (Fig. 7). Differences between Stns 3 and 5 were: (1) the average number and maximal values of epiphytic dinoflagellates associated with it were much higher at Stn $5 ;(2)$ at Stn 3 the peak of abundance of epiphytic dinoflagellates occurred in late July, while at Stn 5 it occurred in late May (note that data before May 24 are lacking); (3) mean peak values of dinoflagellate abundance occurred in mid-October at Stn 3 and in late July at Stn 5; (4) in May to December at Stn 3 the epiphytic dinoflagellates taxocoenosis was dominated by Prorocentrum lima, Coolia monotis and Amphidinium cf. carterae, while at Stn 5 during all the surveys only $P$. lima was the predominant species and $A$. cf. carterae prevailed numerically only once; and 

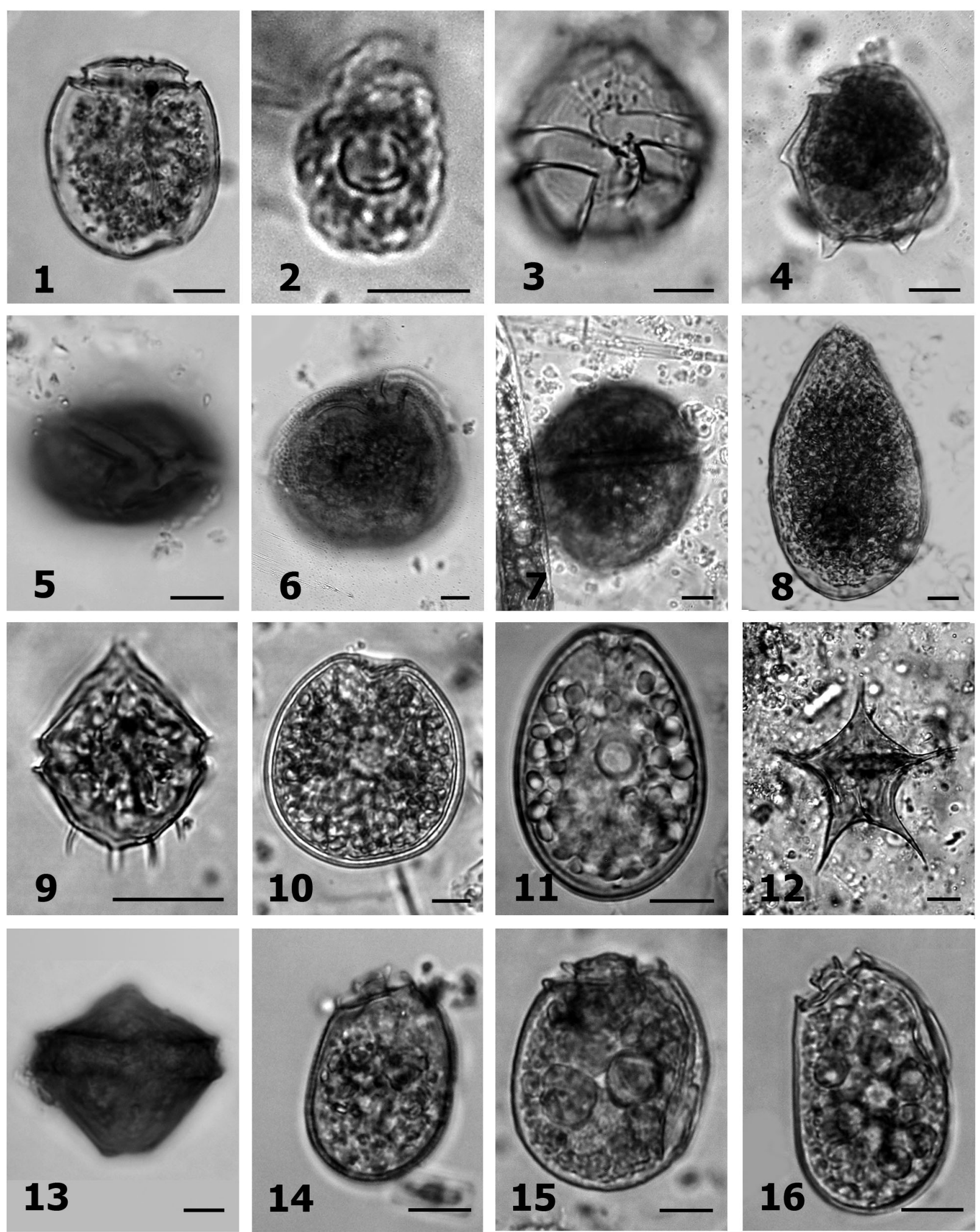

Fig. 6. Benthic and epiphytic dinoflagellates reported from the National Park Sistema Arrecifal Veracruzano: 1, Amphidiniopsis sp.; 2, Amphidinium cf. carterae; 3, (?) Bysmatrum sp., theca; 4, (?) Cabra matta; 5, Coolia monotis; 6, Gambierdiscus cf. toxicus; 7, (?) Gambierdiscus yasumotoi; 8, Ostreopsis heptagona; 9, Peridinium quinquecorne; 10, Prorocentrum concavum; 11, Prorocentrum lima; 12, Protoperidinium compressum, resting cyst; 13, Protoperidinium subinerme, resting cyst; 14, Sinophysis ebriola; 15, Sinophysis microcephala; 16, Sinophysis stenosoma. Scale bars $=10 \mu \mathrm{m}$ 
Table 1. Benthic and epiphytic dinoflagellates found in the National Park Sistema Arrecifal Veracruzano in 2005-2006 (see Fig. 6). ${ }^{*}$ : dominant species; data on the toxicity were taken from published literature. CFP: ciguatera fish poisoning; DSP: diarrheic shellfish poisoning; a question mark indicates doubtful identification

\begin{tabular}{|ll|}
\hline Species & Toxicity \\
\hline Amphidiniopsis sp. & Not toxic \\
Amphidinium cf. carterae & Produces hemolysins \\
Hulburt* & and ichthyotoxins \\
(?) Bysmatrum sp. & Not toxic \\
(?) Cabra matta Murray & Not toxic \\
et Patterson & \\
Coolia monotis Meunier* & Produces cooliatoxin \\
& which is ichthyotoxic \\
Gambierdiscus cf. toxicus & Produces ciguatoxins \\
Adachi et Fukuyo & and maitotoxins; the \\
& main causative agent of \\
& CFP in the tropical zone \\
(?) Gambierdiscus & Produces a toxic substance \\
yasumotoi Holmes & similar to maitotoxins \\
Ostreopsis heptagona Norris, & Toxic to mice \\
Bomber et Balech* & \\
Peridinium quinquecorne & Not toxic \\
T. H. Abé* & \\
Prorocentrum concavum & Produces okadaic \\
Fukuyo & acid and causes DSP \\
Prorocentrum lima (Ehrenb.) & Produces diarrheic toxins: \\
F. Stein* & okadaic acid and proro- \\
& centrolides; cause CFP \\
Prorocentrum spp., benthic & and DSP \\
& Some of them produce \\
Protoperidinium compressum & Not toxic \\
(T. H. Abé) Balech (cysts) & \\
Protoperidinium subinerme & Not toxic \\
(Paulsen) A. R. Loebl. (cysts) & \\
Sinophysis ebriola & Not toxic \\
(Herdman) Balech & \\
Sinophysis microcephala & Not toxic \\
Nie et Wang & \\
Sinophysis stenosoma & Not toxic \\
Hoppenrath & \\
& \\
& \\
& \\
& \\
& \\
& \\
&
\end{tabular}

(5) Ostreopsis heptagona was a component of the dominant complex only at Stn 3 in early May, and it was observed in low numbers at Stn 5 in May 2005. Due to the seasonal occurrence of the majority of the dominant macroalgal species (Table 2), the records of epiphytic dinoflagellates associated with them are discontinuous and sporadic.

\section{Fish mortality event}

On 21 March 2006, when a strong northerly wind blew with a velocity of $8.7 \mathrm{~m} \mathrm{~s}^{-1}$, we observed many dead specimens of the sergeant major Abudefduf sax-
Table 2. Macrophytes associated with benthic and epiphytic dinoflagellates found in the National Park Sistema Arrecifal Veracruzano in 2005-2006.* : dominant species. Chlo: Chlorophyta; Phaeo: Phaeophyta; Rho: Rhodophyta; Ang: Angiospermatophyta. Surveys - 2005: 1, May 10; 2, May 17; 3, May 24; 4, May 31; 5, June 7; 6, July 6; 7, July 13; 8, July 26; 9, August 24; 10, September 13; 11, September 27; 12, October $12 ; 13$, October $18 ; 14$, November $15 ; 15$, November $22 ; 16$, December 13; 2006: 17, January 10 (buoys); 18, February 10 (drifting Sargassum spp.); 19, February 21 (drifting Sargassum spp.); 20, March 3 (buoys)

\begin{tabular}{|c|c|c|}
\hline Species & Division & Surveys \\
\hline $\begin{array}{l}\text { Acanthophora spicifera } \\
\text { (Vahl) Børgesen* }\end{array}$ & Rho & $\begin{array}{l}\text { Stn 3: 1, 2, 9, 14; } \\
\text { Stn 5: 5, 8-11, } 13\end{array}$ \\
\hline $\begin{array}{l}\text { Caulerpa cupressoides } \\
\text { (Vahl) C. Agardh }\end{array}$ & Chlo & $\begin{array}{l}\text { Stn 3: } 10,16 ; \\
\text { Stn 5: } 15\end{array}$ \\
\hline $\begin{array}{l}\text { Caulerpa racemosa (Forssk.) } \\
\text { J. Agardh var. uvifera } \\
\text { (C. Agardh) J. Agardh }\end{array}$ & ) Chlo & Stn 5: 6, 7, 10 \\
\hline $\begin{array}{l}\text { Caulerpa sertularioides } \\
\text { (J. F. Gmel.) Howe* }\end{array}$ & Chlo & $\begin{array}{l}\text { Stn 3: 6, 9, 13; } \\
\text { Stn 5: 5-12 }\end{array}$ \\
\hline $\begin{array}{l}\text { Cladophora sp. (epiphyte } \\
\text { on Thalassia) }\end{array}$ & Chlo & Stn 5: 6, 12, 13 \\
\hline $\begin{array}{l}\text { Codium isthmocladum } \\
\text { Vickers }\end{array}$ & Chlo & Stn 5: 2 \\
\hline Dictyota cervicornis Kütz. & Phaeo & $\begin{array}{l}\text { Stn } 3: 1,2,4,5,7 \\
15\end{array}$ \\
\hline $\begin{array}{l}\text { Galaxaura obtusata } \\
\text { (Ellis et Solander) } \\
\text { J. V. Lamour. }\end{array}$ & Rho & $\begin{array}{l}\text { Stn 3: } 6,7 \\
\text { Stn 5: } 10\end{array}$ \\
\hline Galaxaura squalida Kjellm.* & * Rho & $\begin{array}{l}\text { Stn 3: 5, 6, } \\
\text { Stn 5: } 10\end{array}$ \\
\hline Gracillaria sp. & Rho & $\begin{array}{l}\text { Stn 3: 1, 12; } \\
\text { Stn 5: 5, 6, 8-11, } \\
13,16\end{array}$ \\
\hline $\begin{array}{l}\text { Grateloupia cf. dichotoma } \\
\text { J. Agardh }\end{array}$ & Rho & Stn 5: 6, 9, 10, 12 \\
\hline $\begin{array}{l}\text { Halimeda opuntia (L.) } \\
\text { J. V. Lamour. }^{*}\end{array}$ & Chlo & $\begin{array}{l}\text { Stn } 3: 2-7,9,10 \\
12-16 ; \operatorname{Stn} 5: 3\end{array}$ \\
\hline $\begin{array}{l}\text { Hypnea cervicornis } \\
\text { J. Agardh }\end{array}$ & Rho & Stn 5: 15 \\
\hline $\begin{array}{l}\text { Hypnea musciformis } \\
\text { (Wulfen) J. V. Lamour. }\end{array}$ & Rho & $\begin{array}{l}\text { Stn 3: 15; } \\
\text { Stn 5: } 3\end{array}$ \\
\hline $\begin{array}{l}\text { Hypnea spinella } \\
\text { (C. Agardh) Kütz. }\end{array}$ & Rho & Stn 3: 10 \\
\hline Laurencia sp. & Rho & Stn 3: 5-15 \\
\hline $\begin{array}{l}\text { Padina gymnospora } \\
\text { (Kütz.) Sonder } \\
\text { (attached to buoy cables) }\end{array}$ & Phaeo & Stn 2: 20 \\
\hline Polysiphonia sp. & Rho & Stn 5: 2 \\
\hline $\begin{array}{l}\text { Rhizoclonium sp. } \\
\text { (epiphyte on Thalassia) }\end{array}$ & Chlo & $\operatorname{Stn} 5: 6$ \\
\hline Sargassum filiopendula & Phaeo & $\begin{array}{l}\text { Between Stns } 1 \\
\text { and 2: } 19\end{array}$ \\
\hline \multicolumn{3}{|l|}{ C. Agardh (drifting in masses) } \\
\hline Sargassum vulgare & Phaeo & $\begin{array}{l}\text { Between Stns } 1 \\
\text { and } 2: 18,19\end{array}$ \\
\hline \multicolumn{3}{|l|}{ C. Agardh (drifting in masses) } \\
\hline Ulva fasciata Delile & Chlo & $\operatorname{Stn} 5: 3,4,6$ \\
\hline Ulva lactuca L. & Chlo & $\operatorname{Stn} 5: 2$ \\
\hline Syringodium filiforme Kütz. & Ang & $\begin{array}{l}\text { Isla de Enmedio, } \\
9 \text { April } 2005\end{array}$ \\
\hline $\begin{array}{l}\text { Thalassia testudinum Banks } \\
\text { ex König** }\end{array}$ & Ang & $\begin{array}{l}\text { Stn 3: } 1-16 ; \\
\text { Stn 5: } 1-11,13-16\end{array}$ \\
\hline
\end{tabular}




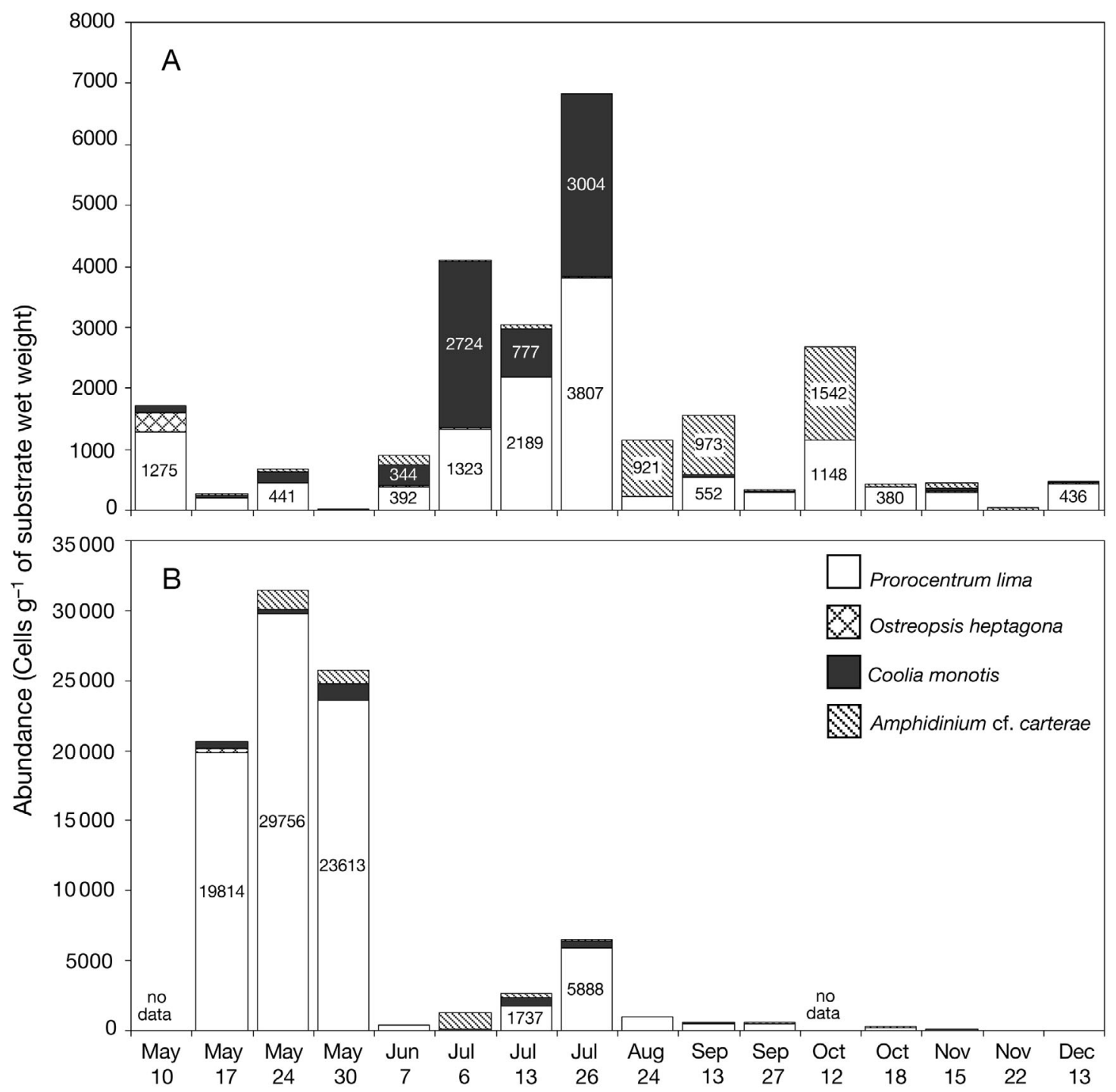

Fig. 7. Seasonal dynamics of the abundance of epiphytic dinoflagellates living on the seagrass Thalassia testudinum in the National Park Sistema Arrecifal Veracruzano at (A) Stn 3 and (B) Stn 5. See Fig. 1 for station locations

atilis (L.), the parrotfish Sparisoma sp. and the surgeonfish Acanthurus sp. tangled in Thalassia testudinum blades on a beach near Stn 5 . Gut content analysis is necessary to prove the presence of toxic dinoflagellates as the main cause of fish mortalities.

\section{DISCUSSION}

\section{Species composition and abundance of dinoflagellates}

Dinoflagellate species richness in the NPSAV can be characterized as relatively low, which is in accordance with that described by Tindall \& Morton (1998) for the type I and II systems. During the sampling period, Prorocentrum lima was almost always dominant. At times, Amphidinium cf. carterae, Coolia monotis and Ostreopsis heptagona also comprised the dominant species complex. The majority of the dinoflagellate population peaks were due mainly to $P$. lima. At Stn 3, the dominance of $P$. lima and C. monotis in May to July 2005 was followed by the prevalence of $A$. cf. carterae in August to October (Fig. 7A). Similarly, in the Florida Keys a decrease in population density of Gambierdiscus toxicus was followed by maximum abundance of P. lima (Bomber et al. 1985). In French Polynesia, seasonal changes in a benthic dinoflagellate taxocoenosis could be traced by both the changes in species composition and cell abundances. During a temporal succes- 
sion a niche vacated by $G$. toxicus was filled by Ostreopsis lenticularis Fukuyo (Bagnis et al. 1990). In addition, Gambierdiscus spp. showed a seasonal cycle in cell densities (Chinain et al. 1999). In east Tasmanian waters during winter, Ostreopsis siamensis Schmidt appears to be replaced by $C$. cf. monotis (Pearce et al. 2001). As regards the main dominant species, our data are in accordance with those of Popowski (1994) for the NW Cuban waters, and, surprisingly, are more similar to the dominant dinoflagellate assemblage found in the regions with the 'Mediterranean' (dry summer/wet winter subtropical) or temperate maritime climate than to that in tropical areas (Pearce et al. 2001, Vila et al. 2001). One should note that the climate of the east Tasmania coast (a temperate region), from which the dinoflagellate assemblage was described (Pearce et al. 2001), differs from the rest of the island, which is more similar to that in West and South Australia with its 'Mediterranean' climate. Because only rare cells of Gambierdiscus cf. toxicus were observed, toxicity studies should concentrate on the most abundant potentially toxic species ( $P$. lima, C. monotis, O. heptagona and $A$. cf. carterae) and their seasonal population dynamics to verify our hypothesis on the risk of ciguatera in the NPSAV.

Species identification of potentially toxic species is crucial. Identification of species of the genus Amphidinium has long been considered problematic, but the genus has been redefined recently (Flø Jørgensen et al. 2004). Amphidinium carterae is extremely similar to A. massartii Biecheler, and because the size range of the 2 species overlaps completely and both species possess a central ring-shaped starch-sheathed pyrenoid, it is difficult to distinguish between them with certainty based on light microscopic observations (Murray et al. 2004). The morphological characteristics distinguishing the 2 species are the shape of the plastid and the slightly different epicone to body length ratio. These differences are not reliably preserved in fixed samples, and therefore we did not identify the species with certainty.

Our data on dinoflagellate abundance associated with macrophytes (at least with Thalassia testudinum and Caulerpa sertularioides $+C$. cupressoides sampled at both stations) support the conclusion of Carlson \& Tindall (1985), who found that protected inshore habitats in the Virgin Islands sustain much greater toxic dinoflagellate cell numbers than coral reefs and related this to the high influence of wave activity which markedly reduces the benthic dinoflagellate population. The drastic decrease in dinoflagellate populations in early June at Stn 5 is hard to explain. In late May to early June, large changes in precipitation (but not in surface water salinity) and in the percentage of DO saturation occurred (Fig. 5D,F).
At Stn 5, Thalassia testudinum reached a larger size than at Stn 3 and on average there were much higher densities of the epiphytic macroalgae Cladophora spp. and Rhizoclonium spp., which predominantly cover the upper parts of $T$. testudinum leaves. These epiphytic macroalgae with their numerous filamentous thalli and high surface:volume ratio, appear to be responsible for greater epiphytic dinoflagellate populations. The highest population density of Prorocentrum lima was observed on 17, 24 and 31 May 2005 at Stn 5 (Fig. 7B), and it seems to be related to T. testudinum leaves with their upper parts densely covered with the macroalgal epiphytes. In the more northern areas, at $41^{\circ} 20^{\prime}$ to $47^{\circ} 35^{\prime} \mathrm{N}$, maximal $P$. lima abundance was observed in late spring-summer and in July to August (Vila et al. 2001, Levasseur et al. 2003).

Few studies have been made of the substrate specificity of benthic/epiphytic dinoflagellates. Bomber et al. (1985) showed that percent ash content and mean Prorocentrum lima abundance were negatively correlated $(\mathrm{r}=-0.3, \mathrm{p}<0.05)$. They hypothesized that host macrophytes with low ash weights are less rigid, allowing more movement in the water column, and that macrophyte surface area should be positively correlated with epiphytic dinoflagellate population density because more space is available for cell division and attachment on high surface area macrophytes. Bomber et al. (1989) also showed that the abundance of Gambierdiscus toxicus was positively correlated $(\mathrm{r}=0.88, \mathrm{p}<0.01)$ with macroalgal host surface area. In the NW Cuban waters, epiphytic dinoflagellates showed no preference for any specific substrate (Popowski 1994). However, determination of the epiphytic dinoflagellate population density related to macroalgal surface area may introduce an additional 20 to $45 \%$ error to each sample (Bomber 1985, Lobel et al. 1988, Morton \& Faust 1997). An increased dinoflagellate biomass was shown to be associated with brown and red macroalgae, with low biomass associated with green algae and seagrasses (Morton \& Faust 1997). In the present study, this holds true only for Halimeda opuntia. Other green algae do not show this trend; moreover, Ulva spp. and Thalassia testudinum had the highest abundance among all studied substrates. Our results are in agreement with the data presented by Bomber et al. (1985), who found P. lima to be the most abundant species on the green algae Halimeda opuntia, Penicillus capitatus Lam. and Avrainvillea nigricans Decne among 16 species of Chlorophyta, Phaeophyta and Rhodophyta, and on the seagrass T. testudinum. Vila et al. (2001) monitored 4 macroalgae species and found that the macroalgal substrate was not significant with respect to association with a certain species of macroalga for all 3 dominant dinoflagellate species. 
Table 3. Abundance of benthic and epiphytic dinoflagellates on various substrates in the National Park Sistema Arrecifal Veracruzano in May to December 2005 (buoys and drifting Sargassum spp. were sampled in January and March 2006); abundance is given in cells per gram of wet substrate weight. See Fig. 1 for station locations

\begin{tabular}{|lcccc|}
\hline Substrate/species & Stn & $\begin{array}{c}\text { Abundance } \\
\text { range } \\
\text { (cells g }\end{array}$ & $\begin{array}{c}\text { Avg. no. } \\
\text { (cells g }\end{array}$ & $\begin{array}{c}\text { No. of } \\
\text { samples }\end{array}$ \\
\hline Acanthophora spicifera & 5 & $2-1372$ & 549 & 6 \\
Caulerpa sertularioides & 3 & $0-464$ & 378 & 6 \\
and C. cupressoides & 5 & $9-2957$ & 742 & 8 \\
Gracilaria sp. & 5 & $0-198$ & 85 & 5 \\
Halimeda opuntia & 3 & $6-365$ & 76 & 12 \\
Laurencia sp. & 3 & $143-3360$ & 2380 & 4 \\
Ulva fasciata & 5 & $2089-30879$ & 12276 & 3 \\
Thalassia testudinum & 3 & $16-6826$ & 1528 & 14 \\
Bottom sediment & 5 & $0-31467$ & 4852 & 12 \\
Sediment on dead corals & 3 & $3-84$ & 35 & 13 \\
Sediment on live corals & 3 & $2-77$ & 16 & 9 \\
Macroalgae attached to & 2 & $0-5039$ & 638 & 8 \\
buoys & 5 & $0-26$ & 16 & 6 \\
Sargassum vulgare and & $1-3$ & $429-1830$ & 1080 & 2 \\
$\quad$ S. filipendula (drifting) & & $4-46-11172$ & 5338 & 11 \\
\hline
\end{tabular}

the number of peaks and the peak periods may vary and are subject to local conditions that might depend on nutrients or sediment load rather than the direct influence of factors such as precipitation, salinity, temperature, wind speed and direction that were similar at the 2 stations. Additionally, the presence and seasonality of epiphytic macroalgae (Cladophora spp. and Rhizoclonium spp. in the case of Thalassia testudinum), which can provide a habitat for dinoflagellates, may be involved. If so, hydrographic and meteorological conditions and bathymetry may be indirectly responsible for the currently inexplicable pronounced differences between Stns 3 and 5 .

Our results differ from what was observed in the Virgin Islands, where toxic epiphytic dinoflagellates demonstrated a bimodal pattern of seasonal abundance with population maxima significantly correlated with regional precipitation and corresponding to the peak periods of rainfall: maximal num-

In some samples of macrophytes at Stn 5, Peridinium quinquecorne was abundant. However, because macrophytes were placed into jars underwater and surrounding water was therefore included, we cannot be sure of the origin of the $P$. quinquecorne cells. They appear to be a part of epiphytic assemblages and could be a causative agent of recurrent red tides observed on 24 May, 4 and 12 August, 12 to 14, 18 and 25 October 2005, and on 20 June, 25 July to 5 August, and 15 August 2006, at Stns 4 and 5, and also northward within the study area, always very close to the coastline. This species, which is characterized by high swimming velocity, has been shown to be able to move out of the water column and to attach to solid objects away from the light and seems to follow intrinsic tide-dependent oscillations (Horstmann 1980). Additional studies are needed to show the relevance of $P$. quinquecorne to benthic/epiphytic assemblages in the NPSAV.

\section{Seasonality and relationships between abiotic factors and abundance of dinoflagellates}

Due to the length of our sampling period (8 mo), we cannot draw any conclusions about the number of dinoflagellate abundance peaks exhibited at Stns 3 and 5 during a calendar year (Fig. 7). However, it is evident that, despite the proximity of these 2 sampling sites, bers of most of the studied species usually followed periods of heavy rainfall (Carlson \& Tindall 1985). In addition, in the Virgin Islands, all 7 dinoflagellate species studied were positively or negatively correlated with water temperature, and 2 species were positively correlated with $\mathrm{NO}_{3}-\mathrm{N}, \mathrm{NH}_{4}-\mathrm{N}$, dissolved $\mathrm{PO}_{4}-\mathrm{P}$ and total dissolved phosphorus. In east Tasmanian waters, a decrease in temperature was associated with a decline in dinoflagellate numbers through winter (Pearce et al. 2001). In contrast, in southwestern Puerto Rico, 2 dominant epiphytic dinoflagellate species were not strongly correlated with temperature or rainfall, although they displayed seasonal fluctuations over a 3 yr period (Ballantine et al. 1988). In Japan, no correlation between the abundance of Gambierdiscus toxicus and nutrients was demonstrated (Yasumoto et al. 1980). In Queensland, Australia, periodicity in the $G$. toxicus abundance does not seem to be related directly to temperature, and complex substrate interactions and other unknown factors appear to be involved (Gillespie et al. 1985). Summing up, seasonality of $G$. toxicus is observed sometimes, but not always, and the underlying factors that control population increases of this species remain unknown (Cruz-Rivera \& Villareal 2006). In the NW Mediterranean, no significant correlations were observed between epiphytic dinoflagellates and water temperature or nutrients; however, the epiphytic dinoflagellate assemblage demonstrated a clear seasonality (Vila et al. 2001). 
Regarding the relationship of the benthic/epiphytic dinoflagellate abundance and winds, only a few observations are available. For example, during the warmest months in the Virgin Islands, on windless days the abundance of many species diminished (Carlson \& Tindall 1985). According to our factor analysis, no evident relationship occurred between dinoflagellates and physical-chemical factors in the NPSAV. Nevertheless, in October 2005, northerly winds could have contributed to the decrease in the epiphytic dinoflagellate population density, although even stronger winds (up to 10.6 to $11.9 \mathrm{~m} \mathrm{~s}^{-1}$ ) were recorded after the sampling period, in November 2005, January and February 2006. Most of the epiphytic dinoflagellates found in the NPSAV did not show any particular preference for macrophyte species. However, the seagrass Thalassia testudinum appears to be the most abundant and permanent host.

Other studies have concluded that the availability of macroalgal substrates, light intensity and water movements affected the spatial distribution of epiphytic dinoflagellates while precipitation, temperature and nutrients from macroalgae are important temporary factors (Carlson \& Tindall 1985, Tindall \& Morton 1998). Increases in cell abundance may result from the colonization of the substrate by free-living cells and/or in situ growth of already attached cells, while decreases in abundance may result from detachment or mortality of attached cells and/or loss of substrate. Therefore, the temporal patterns should be interpreted with respect to the succession of host macroalgae (Levasseur et al. 2003). In addition, macroalgal surface area and ash content appear to be regulating factors of dinoflagellate population density (Bomber et al. 1985). Depending on the geographic region, Gambierdiscus toxicus has been shown to prefer different macroalgal host species and has been found with more than 50 algal genera (Shimizu et al. 1982, Carlson \& Tindall 1985, Lobel et al. 1988, Cruz-Rivera \& Villareal 2006).

\section{Potential risk of ciguatera}

The present study, as well as others in the Caribbean and elsewhere, showed that not only Gambierdiscus toxicus but also other toxic benthic/epiphytic dinoflagellate species can be a major component of the assemblages, and that additional ecological studies of ciguatera endemic areas should focus on species in addition to G. toxicus, especially those of the genera Prorocentrum, Ostreopsis, Coolia and Amphidinium (Besada et al. 1982, Bagnis et al. 1985, Bomber et al. 1985, 1988, Carlson \& Tindall 1985, Ballantine et al. 1988, Popowski 1994, Bourdeaux et al. 1995, Faust 1995a, Morton \& Faust 1997, Heil et al. 1998, Tindall \& Morton 1998, Tosteson et al. 1998, Turquet et al. 1998).
Among the dinoflagellate species of the NPSAV, Prorocentrum lima, Coolia monotis, Ostreopsis heptagona, and Gambierdiscus cf. toxicus can be considered potentially ciguateric species because they have been reported as toxic elsewhere (Nakajima et al. 1981, Norris et al. 1985, Yasumoto et al. 1987). Amphidinium cf. carterae requires a more thorough identification.

Seventeen fish species have been reported from the reef lagoon of Isla de Sacrificios. The following taxa were the most common: among herbivorous grazers, the dusky damsel Stegastes fuscus (Cuvier in Cuvier et Valenciennes), the Cocoa damselfish S. variabilis (Castelnau) and spotfin butterfly Chaetodon ocellatus Bloch; among benthic and demersal predators and planktivorous species, the slippery dick wrasse Halichoeres bivittatus (Bloch), the flagfin mojarra Eucinostomus melanopterus (Bleeker), the grey snapper Lutjanus griseus (L.), the silver jenny E. gula (Quoy et Gaimard), the sergeant major Abudefduf saxatilis, the yellowtail snapper Ocyurus chrysurus (Bloch) and the rock hind Epinephelus adscensionis (Osbeck) (H. Pérez-España pers. comm., August 2006). The great barracuda Sphyraena barracuda (Walbaum) was the only pelagic predator reported. L. griseus, O. chrysurus, E. adscensionis, $S$. barracuda, Sparisoma sp. and Acanthurus chirurgus (Bloch) contribute to the commercial catch in the study area (Jiménez-Badillo et al. 2006).

The presence of a typical ciguateric food chain in the NPSAV indicates the potential involvement of at least some of the recorded fish species in the transfer of ciguatera. In the Mexican Caribbean, the southern Gulf of Mexico, the Gulf of California and the west coast of the State of Baja California Sur, all ciguatera intoxications are ascribed to the carnivorous fish from the genera Lutjanus Bloch, Epinephelus Bloch, Mycteroperca Gill, Semicossyphus Günther, Sphoeroides Anonymous [Lacepède], Arothron Müller and Canthigaster Swainson, as well as to Sphyraena barracuda (Parrilla-Cerrillo et al. 1993, Barton et al. 1995, Lechuga-Devéze \& Sierra-Beltrán 1995, NúñezVázquez et al. 2000, Núñez-Vázquez 2005); 3 of these taxa have been recorded in the NPSAV. In Puerto Rico, the transmission of the dinoflagellate toxins through herbivorous reef fishes to their barracuda predators must take place in a relatively short period of time, and barracudas showed the highest ciguatoxicity after several months of exposure to sustained, elevated sea surface temperatures (Tosteson et al. 1998).

Growth rates of toxic epiphytic dinoflagellates from the tropical and temperate zones range from 0.05 to 0.53 divisions $\mathrm{d}^{-1}$, and even a rate of $>0.6$ divisions $\mathrm{d}^{-1}$ could be sustained under optimal conditions of light, salinity and temperature (Bomber et al. 1988, 1989, Morton \& Norris, 1990, Heil et al. 1993, Jackson et al. 1993, Pearce et al. 2001, Levasseur et al. 2003). The 
high toxin-producing epiphytic dinoflagellate densities found and their short generation time known from literature, the shallowness of numerous reef zones inhabited by seagrasses and macroalgae, and the presence of a typical coral reef ichthyocoenosis indicate a high potential for outbreaks of ciguatera in the study area.

\section{CONCLUSIONS}

Although many important aspects of the studied benthic/epiphytic dinoflagellate assemblages (e.g. toxicity, light and depth preference, small-scale distribution, correct identification of Prorocentrum spp. and some rare species from other genera, and methodological problems of sampling and counting) remained beyond the scope of the present study, we can draw several conclusions. (1) Low species diversity and high abundance characterized the assemblage of benthic/ epiphytic dinoflagellates in the NPSAV; Prorocentrum lima was the main dominant species. (2) In the study area benthic and epiphytic dinoflagellates occurred in a wide range of habitats and associated with various sessile and drifting macrophytes, dead and live corals, and sediments. (3) Most of the epiphytic dinoflagellates did not show any significant preference for macrophyte species, although the seagrass Thalassia testudinum appears to be the most abundant and permanent host species. (4) The assemblage demonstrated clear seasonal dynamics, being more abundant in May to June. The assemblage differed at 2 neighbouring sampling sites. (5) The population density of benthic/ epiphytic dinoflagellates was not found to be correlated with any measured physical-chemical parameter. Finally, there is a high potential for outbreaks of ciguatera in the NPSAV, and the implementation of a monitoring program for early detection of non-pelagic harmful algal blooms, especially in the ciguatera endemic regions, is therefore necessary.

Acknowledgements. We thank M. A. Román-Vives, H. LeónTejera, H. Pérez-España, R. Aguilar-Durán, J. Lara-Morales, R. Salgado-Torres, N. Meza-Domínguez, M. AlvaradoTejeda, L. Magaña-Ruíz, L. Uscanga-Pérez, D. Corro-Vásquez, G. Ramírez-Reséndiz, E. J. Núñez-Vázquez, F. Acevedo-Rosas, and all others who helped us. B. Okolodkov is thanked for technical assistance with illustrations. H. Esson and M. M. Gowing, kindly improved the language style. We are also grateful to 3 anonymous reviewers and the copyeditor for their critical comments. The financial support of PROMEP, Mexico, given to Y.B.O. (the project UVER-PTC-144) in 2005-2006, and the financial and logistic support of the Acuario de Veracruz and of CICIMAR-IPN projects (SIP-20060332, 20060137 ) to I.G.-L. are very much appreciated. I.G.-L. received a fellowship from COFAA (Comisión de Cooperación y Fomento de Actividades Académicas) and EDI (Estímulos al Desempeño de los Investigadores).

\section{LITERATURE CITED}

Almazán-Becerril A (2000) Estudio taxonómico de algunos dinoflagelados potencialmente tóxicos en el Caribe Mexicano. Tesis de Maestría, Universidad Nacional Autónoma de México, México DF

Bagnis B, Bennett J, Prieur C, Legrand AM (1985) The dynamics of three toxic benthic dinoflagellates and the toxicity of ciguateric surgeonfish in French Polynesia. In: Anderson DM, White AW, Baden DG (eds) Toxic dinoflagellates. Elsevier Science, New York, p 177-182

Bagnis R, Legrand AM, Inoue A (1990) Follow-up of a bloom of the toxic dinoflagellate Gambierdiscus toxicus on a fringing reef of Tahiti. In: Granéli E, Sundsröm B, Edler L, Anderson D (eds) Toxic marine phytoplankton. Elsevier Science, New York, p 98-103

Baillie KD (1971) A taxonomic and ecological study of intertidal sand-dwelling dinoflagellates of the north eastern Pacific Ocean. MS thesis, University of British Columbia, Vancouver

Balech E (1956) Étude des dinoflagellés du sable de Roscoff. Rev Algol 2:29-52

Ballantine DL, Tosteson TR, Bardales AT (1988) Population dynamics and toxicity of natural populations of benthic dinoflagellates in southwestern Puerto Rico. J Exp Mar Biol Ecol 119:201-212

Barton ED, Tanner P, Turchen SG, Tunget CL, Manoguerra A, Clark RF (1995) Ciguatera fish poisoning - a Southern California epidemic. West J Med 163:31-35

Besada EG, Loeblich LA, Loeblich AR III (1982) Observations on tropical, benthic dinoflagellates from ciguateraendemic areas: Coolia, Gambierdiscus, and Ostreopsis. Bull Mar Sci 32(3):723-735

Bomber JW (1985) Ecological studies of benthic dinoflagellates associated with ciguatera from the Florida Keys. MS thesis, Florida Institute of Technology, Melbourne, FL

Bomber JW, Norris DR, Mitchell LE (1985) Benthic dinoflagellates associated with ciguatera from the Florida Keys. II. Temporal, spatial and substrate heterogeneity of Prorocentrum lima. In: Anderson DM, White AW, Baden DG (eds) Toxic dinoflagellates. Elsevier Science, New York, p $45-50$

Bomber JW, Morton SL, Babinchak JA, Norris DR, Morton JG (1988) Epiphytic dinoflagellates of drift algae-another toxigenic community in the ciguatera food chain. Bull Mar Sci 43:204-214

Bomber JW, Rubio MG, Norris DR (1989) Epiphytism of dinoflagellates associated with the disease ciguatera: substrate specificity and nutrition. Phycologia 28:360-368

Bourdeaux P, Durand-Clement M, Ammar M, Fessard V (1995) Ecological and toxicological characteristics of benthic dinoflagellates in a ciguateric area (Saint Barthelemy: French West Indies). In: Lassus P, Arzul G, Erard-Le Denn E, Gentien P, Marcaillou-Le Baut C (eds) Harmful marine algal blooms. Technique \& Documentation - Lavoisier, London, p 133-137

Carlson RD, Tindall DR (1985) Distribution and periodicity of toxic dinoflagellates in the Virgin Islands. In: Anderson DM, White AW, Baden DG (eds) Toxic dinoflagellates. Elsevier Science, New York, p 171-176

Chinain M, Germain M, Deparis X, Pauillac S, Legrand AM (1999) Seasonal abundance and toxicity of the dinoflagellate Gambierdiscus spp. (Dinophyceae), the causative agent of ciguatera in Tahiti, French Polynesia. Mar Biol 135:259-267

Cruz-Rivera E, Villareal TA (2006) Macroalgal palatability and the flux of ciguatera toxins through marine food webs. 
Harmful Algae 5:497-525

Delgado G, Popowski G, Pombo MC (2002) Nuevos registros de dinoflagelados epibénticos en Cuba. Rev Invest Mar 23(3):229-232

Delgado G, Popowski G, García C, Lagos N, Lechuga-Devéze C (2005) Presence of DSP-toxins in Prorocentrum lima (Ehrenberg) Dodge in Cuba. Rev Invest Mar 26(3): 229-234

Dodge JD, Lewis J (1986) A further SEM study of armoured sand-dwelling marine dinoflagellates. Protistologica 22: 221-230

Faust MA (1990) Morphologic details of six benthic species of Prorocentrum (Pyrrophyta) from a mangrove island, Twin Cays, Belize, including two new species. J Phycol 26:548-558

Faust MA (1995a) Benthic, toxic dinoflagellates: an overview. In: Lassus P, Arzul G, Erard-Le Denn E, Gentien P, Marcaillou-Le Baut C (eds) Harmful marine algal blooms. Technique \& Documentation - Lavoisier, London, p 847-854

Faust MA (1995b) Observation on sand-dwelling toxic dinoflagellates (Dinophyceae) from widely differing sites, including two new species. J Phycol 31:996-1003

Faust MA, Balech E (1993) A further SEM study of marine benthic dinoflagellates from a mangrove island, Twin Cays, Belize, including Plagiodinium belizeanum gen. et sp. nov. J Phycol 29:826-832

Flø Jørgensen M, Murray S, Daugbjerg N (2004) Amphidinium revisited. I. Redefinition of Amphidinium (Dinophyceae) based on cladistic and molecular phylogenetic analyses. J Phycol 40:351-365

Fukuyo Y (1981) Taxonomical study on benthic dinoflagellates collected in coral reefs. Bull Jpn Soc Sci Fish 47:967-978

Gillespie NC, Holmes MJ, Burke JB, Doley J (1985) Distribution and periodicity of Gambierdiscus toxicus in Queensland, Australia. In: Anderson DM, White AW, Baden DG (eds) Toxic dinoflagellates. Elsevier Science, New York, p 183-188

Heil CA, Maranda L, Shimizu Y (1993) Mucus-associated dinoflagellates: large scale culturing and estimation of growth rate. In: Smayda TJ, Shimizu Y (eds) Toxic phytoplankton blooms in the sea. Elsevier Science, Amsterdam, p 501-506

Heil CA, Bird P, Dennison WC (1998) Macroalgal habitat preference of ciguatera dinoflagellates at Heron Island, a coral cay in the southerneastern Great Barrier Reef, Australia. In: Reguera B, Blanco J, Fernández ML, Wyatt T (eds) Harmful algae. Intergovernmental Oceanographic Commission of UNESCO, Xunta de Galicia, Vigo, p 52-53

Herdman EC (1921) Notes on dinoflagellates and other organisms causing discolouration of the sand at Port Erin. Proc Trans Liverpool Biol Soc 35:59-63

Hernández-Becerril DU, Almazán-Becerril A (2004) Especies de dinoflagelados del género Gambierdiscus (Dinophyceae) del Mar Caribe mexicano. Rev Biol Trop 52(Suppl 1):77-87

Holmes MJ, Lee FC, Ming Teo SL, Woo Khoo H (1998) A survey of benthic dinoflagellates on Singapore reefs. In: Reguera B, Blanco J, Fernández ML, Wyatt T (eds) Harmful algae. Intergovernmental Oceanographic Commission of UNESCO, Xunta de Galicia, Vigo, p 50-51

Hoppenrath M (2000a) An emended description of Herdmania litoralis Dodge (Dinophyceae) including the plate formula. Nova Hedw 71:481-489

Hoppenrath M (2000b) Morphology and taxonomy of Sinophysis (Dinophyceae, Dinophysiales) including two new marine sand-dwelling species from the North German
Wadden Sea. Eur J Phycol 35:153-162

Hoppenrath M (2000c) Morphology and taxonomy of six marine sand-dwelling Amphidiniopsis species (Dinophyceae, Peridiniales), four of them new, from the German Bight, North Sea. Phycologia 39:482-497

Hoppenrath M (2000d) Morphology and taxonomy of the marine sand-dwelling genus Thecadinium (Dinophyceae), with the description of two new species from the North German Wadden Sea. Phycologia 39:96-108

Hoppenrath M, Schweikert M, Elbrächter M (2003) Morphological reinvestigation and characterization of the marine, sand-dwelling dinoflagellate Adenoides eludens (Dinophyceae). Eur J Phycol 38:385-394

Hoppenrath M, Saldarriaga JF, Schweikert M, Elbrächter M, Taylor FJR (2004) Description of Thecadinium mucosum sp. nov. (Dinophyceae), a new sand-dwelling marine dinoflagellate, and an emended description of Thecadinium inclinatum Balech. J Phycol 40:946-961

Horiguchi T (1995) Amphidiniella sedentaria gen. et sp. nov. (Dinophyceae), a new sand-dwelling dinoflagellate from Japan. Phycol Res 43:93-99

Horiguchi T, Chihara M (1987) Spiniferodinium galeiforme, a new genus and species of benthic dinoflagellates (Phytodiniales, Pyrrhophyta) from Japan. Phycologia 26: 478-487

Horiguchi T, Sukigara C (2005) Pyramidodinium atrofuscum gen. et sp. nov. (Dinophyceae), a new marine sanddwelling coccoid dinoflagellate from tropical waters. Phycol Res 53:247-254

Horiguchi T, Yoshizawa-Ebata J, Nakayama T (2000) Halostylodinium arenarium, gen. et sp. nov. (Dinophyceae), a coccoid sand-dwelling dinoflagellate from subtropical Japan. J Phycol 36:960-971

Horstmann U (1980) Observations on the peculiar diurnal migration of a red tide Dinophyceae in tropical shallow waters. J Phycol 16:481-485

Jackson AE, Marr JC, McLachlan JL (1993) The production of diarrheic shellfish toxins by an isolate of Prorocentrum lima from Nova Scotia, Canada. In: Smayda TJ, Shimizu Y (eds) Toxic phytoplankton blooms in the sea. Elsevier Science, Amsterdam, p 513-518

Jiménez-Badillo ML, Pérez-España $H$, Vargas-Hernández JM, Cortés-Salinas JC, Flores-Pineda P (2006) Catálogo de especies y artes de pesca artesanal del Parque Nacional Sistema Arrecifal Veracruzano. CONABIO, Universidad Veracruzana, México DF, Xalapa, Veracruz

Larsen J (1985) Algal studies of the Danish Wadden Sea. II. A taxonomic study of psammobious dinoflagellates. Opera Bot 79:14-37

Lebour MV (1925) The dinoflagellates of Northern Seas. Marine Biological Association, Plymouth

Lechuga-Devéze CH, Sierra-Beltrán AP (1995) Documented case of ciguatera on the Mexican Pacific coast. Natural Toxins 3:415-418

Levasseur M, Couture JI, Weise AM, Michaud S, Elbrächter M, Sauvé G, Bonneau E (2003) Pelagic and epiphytic summer distributions of Prorocentrum lima and $P$. mexicana at two mussel farms in the Gulf of St. Lawrence, Canada. Aquat Microb Ecol 30:283-293

Lobel PS, Anderson DM, Durand-Clement M (1988) Assessment of ciguatera dinoflagellate populations: sample variability and algal substrate selection. Biol Bull 175:94-101

Morton SL, Faust MA (1997) Survey of toxic epiphytic dinoflagellates from the Belizean Barrier Reef Ecosystem. Bull Mar Sci 61(3):899-906

Morton SL, Norris DR (1990) Role of temperature, salinity, and light on the seasonality of Prorocentrum lima (Ehrenberg) 
Dodge. In: Granéli E, Sundsröm B, Edler L, Anderson D (eds) Toxic marine phytoplankton. Elsevier Science, New York, p 201-205

Murray S, Flø Jørgensen M, Daugbjerg N, Rhodes L (2004) Amphidinium revisited. II. Resolving species boundaries in the Amphidinium operculatum species complex (Dinophyceae), including the description of Amphidinium trulla sp. nov. and Amphidinium gibbosum comb. nov. J Phycol 40:366-382

Murray S, Hoppenrath M, Larsen J, Patterson DJ (2006a) Bysmatrum teres sp. nov., a new sand-dwelling dinoflagellate from north-western Australia. Phycologia 45: 161-167

Murray S, Hoppenrath M, Preisfeld A, Larsen J, Yoshimatsu S, Toriumi S, Patterson D (2006b) Phylogenetics of Rhinodinium broomeense gen. et sp. nov., a peridinioid, sanddwelling dinoflagellate (Dinophyceae). J Phycol 42: 934-942

Nakajima I, Oshima Y, Yasumoto T (1981) Toxicity of benthic dinoflagellates in Okinawa. Bull Jpn Soc Sci Fish 47: 1029-1033

Norris DR, Bomber JW, Balech E (1985) Benthic dinoflagellates associated with ciguatera from the Florida Keys. I. Ostreopsis heptagona sp. nov. In: Anderson DM, White AW, Baden DG (eds) Toxic dinoflagellates. Elsevier Science, New York, p 39-44

Núñez-Vázquez EJ (2005) Biotoxinas marinas en peces comestibles de Baja California Sur, México: origen, identificación y cuantificación. Tesis de Licenciatura. Centro de Investigaciones Biológicas del Noroeste, La Paz, Baja California Sur

Núñez-Vázquez EJ, Almazán-Becerril A, Heredia-Tapia A, Hernández-Becerril DU and 5 others (2000) Incidencia del envenenamiento por ciguatera en México. Resúmenes de la 4a Reunión de Expertos en Envenenamientos por Animales Ponzoñosos, Cuernavaca, Morelos, p 49-50

Okolodkov YB, Gárate-Lizárraga I (2006) An annotated checklist of dinoflagellates (Dinophyceae) from the Mexican Pacific. Acta Bot Mexicana 72:1-154

Parrilla-Cerrillo MC, Vásquez-Castellanos JL, Saldate-Castañeda EO, Nava-Fernández LM (1993) Brotes de toxiinfecciones alimentarias de origen microbiano y parasitario. Salud Pública de México 35(5):456-462

Pearce I, Marshall JA, Hallegraeff GM (2001) Toxic epiphytic dinoflagellates from east coast Tasmania, Australia. In: Hallegraeff GM, Blackburn SI, Bolch CJ, Lewis RJ (eds) Harmful algal blooms 2000. Intergovernmental Oceanographic Commission of UNESCO, Hobart, Tasmania, p 54-57

Popowski G (1994) Dinoflagelados asociados con la ciguatera en aguas cubanas. In: VII Reunión Nacional de la Sociedad Mexicana de Planctología, A.C. Resúmenes, 27 al 29 de abril de 1994, La Paz, Baja California Sur

Schuhmacher H (1978) Arrecifes coralinos: su extensión, mundo animal y ecología. Ediciones Omega, Barcelona

Editorial responsibility: Edna Granéli,

Kalmar, Sweden
Shimizu Y, Shimizu H, Scheuer J, Hokama Y, Oyama M, Miyahara JT (1982) Gambierdiscus toxicus, a ciguateracausing dinoflagellate from Hawaii. Bull Jpn Soc Sci Fish 48:811-813

Suárez-Hernández M, Arteaga-Águila ME, Méndez-Achón JC, Cortés-Ferrer J, Blanco-Rojas R (2001) Epidemiología de la ciguatera en 16 años de estudio en la provincia de Ciego de Ávila. Rev Cubana Hig Epidemiol 39(3):164-171

Tamura M, Shimada S, Horiguchi T (2005) Galeidinium rugatum gen. et sp. nov. (Dinophyceae), a new coccoid dinoflagellate with a diatom endosymbiont. J Phycol 41: 658-671

Taylor FJR (1978) Dinoflagellates. Identification problems. Some specific preparations, Chapter 6. In: Sournia A (ed) Phytoplankton manual. Monographs on oceanographic methodology, 6. UNESCO, Paris, p 143-147

Taylor FJR (1979) The toxigenic gonyaulacoid dinoflagellates. In: Taylor DL, Seliger HH (eds) Toxic dinoflagellate blooms. Elsevier/North-Holland, New York, p 47-56

Ten-Hage L, Quod JP, Turquet J, Couté A (2001) Bysmatrum granulosum sp. nov., a new benthic dinoflagellate from the southwestern Indian Ocean. Eur J Phycol 36:129-135

Tindall DR, Morton SL (1998) Community dynamics and physiology of epiphytic/benthic dinoflagellates associated with ciguatera. In: Anderson DM, Cembella AD, Hallegraeff GM (eds) Physiological ecology of harmful algal blooms. NATO ASI Series, Series G: Ecological Sciences 41. Springer-Verlag, Berlin, p 293-313

Tindall DR, Miller DM, Tindall PM (1990) Toxicity of Ostreopsis lenticularis from the British and United States Virgin Islands. In: Granéli E, Sundsröm B, Edler L, Anderson D (eds) Toxic marine phytoplankton. Elsevier Science, New York, p 424-429

Tosteson TR, Ballantine DL, Winter A (1998) Sea surface temperature, benthic dinoflagellate toxicity and toxin transmission in the ciguatera food web. In: Reguera B, Blanco J, Fernández ML, Wyatt T (eds) Harmful algae. Intergovernmental Oceanographic Commission of UNESCO, Xunta de Galicia, Vigo, p 48-49

Turquet J, Quad JP, Couté A, Faust MA (1998) Assemblage of benthic dinoflagellates and monitoring of harmful species in Reunion Island, SW Indian Ocean, 1993-1996. In: Reguera B, Blanco J, Fernández ML, Wyatt T (eds) Harmful algae. Intergovernmental Oceanographic Commission of UNESCO, Xunta de Galicia, Vigo, p 44-47

Vila M, Garcés E, Masó M (2001) Potentially toxic epiphytic dinoflagellate assemblages on macroalgae in the NW Mediterranean. Aquat Microb Ecol 26:51-60

Yasumoto $\mathrm{T}$, Inoue A, Tadashi O, Fujimoto $\mathrm{K}$, Oshima $\mathrm{Y}$, Fukuyo Y, Adachi R, Bagnis R (1980) Environmental studies on a toxic dinoflagellate responsible for ciguatera. Bull Jpn Soc Sci Fish 46:1397-1404

Yasumoto T, Seino N, Yasutaka M, Murata M (1987) Toxins produced by benthic dinoflagellates. Biol Bull 172: 128-131

Submitted: September 13, 2006; Accepted: March 14, 2007

Proofs received from author(s): May 19, 2007 